\title{
Enhanced expression of the LRP-I transporter at the blood-CSF interface in chronic hydrocephalus
}

\author{
Conrad E Johanson*1, Petra M Klinge ${ }^{2}$, Sarah Soltman ${ }^{1}$, Stephanie Flaherty ${ }^{1}$, \\ Arthur Messier ${ }^{1}$, John A Duncan III ${ }^{1}$, Edward G Stopa ${ }^{3}$ and \\ Gerald D Silverberg ${ }^{1}$
}

Address: ${ }^{1}$ Department of Clinical Neuroscience, Brown Medical School, Providence, RI 02903, USA, ${ }^{2}$ Department of Neurosurgery, International Neuroscience Institute, Hanover 30625, Germany and ${ }^{3}$ Division of Neuropathology, Brown Medical School, Providence, RI 02903, USA

Email: Conrad E Johanson* - Conrad_Johanson@brown.edu

* Corresponding author

from 5 I $^{\text {st }}$ Annual Meeting of the Society for Research into Hydrocephalus and Spina Bifida Heidelberg, Germany. 27-30 June 2007

Published: 20 December 2007

Cerebrospinal Fluid Research 2007, 4(Suppl I):S45 doi:I0.I I86/I743-8454-4-SI-S45

This abstract is available from: http://www.cerebrospinalfluidresearch.com/content/4/SI/S45

(C) 2007 Johanson et al; licensee BioMed Central Ltd.

\section{Background}

Reduced CSF formation in chronic hydrocephalus (NPH) prompts the question of how the expression of choroid epithelial transporters is altered when flow is disrupted. In the Kaolin model of communicating hydrocephalus, we previously demonstrated that choroid plexus chloride transport (proportional to CSF production) is significantly decreased [1]. To investigate the expression of other choroidal transporters that effect CSF homeostasis, we have now analyzed the time course of LRP-1 expression in the plexus at various stages of hydrocephalus. LRP-1 is a transporter that mediates efflux of A-Beta peptide from the CSF. We postulate that LRP-1 in choroid plexus has a key absorptive role that stabilizes A-Beta in the CNS.

\section{Materials and methods}

In 15 Sprague-Dawley (SD) rats at 12 mo of age, we injected Kaolin into the cisterna magna to induce an NPH-like hydrocephalus. Animals were analyzed at 2, 6 and 10 weeks post-induction. Ventriculomegaly was confirmed by 4.7 Tesla MRI. Choroidal tissues were removed from the lateral ventricles and immunostained with antibody against LRP-1 or analyzed by quantitative (q) PCR to determine LRP-1 transcript levels. 4-5 rats were analyzed at each stage.

\section{Results}

Compared to controls, there was enhanced immunostaining of LRP-1 in the choroidal epithelium at $2 \mathrm{wk}$ and $6 \mathrm{wk}$ post-induction. At $10 \mathrm{wk}$, LRP-1 staining was even greater than at 2 and $6 \mathrm{wk}$, being especially marked at the apical (CSF-facing) pole of the epithelium. Apically-located LRP1 can actively remove A-Beta from the CSF [2]. The immuno-histochemistry findings were corroborated by qPCR. Thus, LRP-1 transcript in choroid plexus, compared to control, was augmented even at $2 \mathrm{wk}$. Upregulated LRP$1 \mathrm{mRNA}$ in the plexus was sustained at 6 and $10 \mathrm{wk}$. For comparison, we analyzed LRP-1 mRNA in human choroid plexus from patients with Alzheimer's disease (AD), a condition in which NPH often coexists. LRP-1 expression was also maintained in $\mathrm{AD}$ choroid plexus (i.e., the bloodCSF interface), unlike the cortical microvessels in $\mathrm{AD}$, which lose LRP-1 [3].

\section{Conclusion}

When comparing NPH and AD with aging responses, there are contrasting differences in the expression patterns of LRP-1 at the blood-CSF vs. blood-brain interfaces. The ability of choroid plexus to sustain, and even increase, LRP-1 expression in chronic hydrocephalus suggests that the blood-CSF transport interface may help to cover deficient LRP-1 expression in cerebral capillaries in aging, $\mathrm{NPH}$ and $\mathrm{AD}$. 


\section{Support}

Saunders Fund, Neurosurgery Foundation, and NIA R01

AG027910.

\section{References}

I. Knuckey NW, Preston J, Palm D, Epstein MH, Johanson C: Hydrocephalus decreases chloride efflux from the choroid plexus epithelium. Brain Res 1993, 618:313-317.

2. Crossgrove JS, Li GJ, Zheng W: The choroid plexus removes beta-amyloid from brain cerebrospinal fluid. Exp Biol Med 2005, 230:77I-776.

3. Donahue JE, Flaherty SL, Johanson CE, Duncan JA III, Silverberg GD, Miller MC, Tavares R, Yang W, Wu Q, Sabo E, Hovanesian V, Stopa EG: RAGE, LRP-I, and amyloid-beta protein in Alzheimer's disease. Acta Neuropathol 2006, I I 2:405-4I5.

Publish with Biomed Central and every scientist can read your work free of charge

"BioMed Central will be the most significant development for disseminating the results of biomedical research in our lifetime. " Sir Paul Nurse, Cancer Research UK

Your research papers will be:

- available free of charge to the entire biomedical community

- peer reviewed and published immediately upon acceptance

- cited in PubMed and archived on PubMed Central

- yours - you keep the copyright

Submit your manuscript here:

http://www.biomedcentral.com/info/publishing_adv.asp 